\title{
HUBUNGAN ANTARA TANGGUNG JAWAB SOSIAL, KUALITAS PELAYANAN, DAN CITRA PERUSAHAAN TERHADAP LOYALITAS NASABAH BSI SURABAYA
}

\author{
Fauzie Senoaji ${ }^{1}$ \\ 1,Program Studi Manajemen, Fakultas Ekonomi dan Bisnis, Universitas Muhammadiyah Surabaya \\ *)fauziesenoaji@fe.um-surabaya.ac.id
}

\begin{abstract}
Informasi Artikel
Draft awal: September 2021

Revisi : September 2021

Diterima : September 2021

Available online: September 2021

Keywords: Corporate social responsibility, Quality Service, Corporate Image, Customer loyalty.
\end{abstract}

Tipe Artikel : Research paper

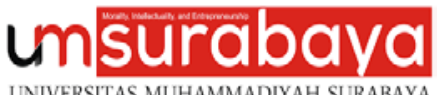

Diterbitkan oleh Universitas Muhammadiyah Surabaya

\section{ABSTRACT}

This study aims to analyze the effect of corporate social responsibility, service quality, and corporate image on customer loyalty. The source of this research data is primary data from the sample, namely the customers of Bank Syariah Indonesia (BSI) Surabaya Branch. This research is a quantitative research with causality research technique. The independent variables of this research are corporate social responsibility $(X 1)$, service quality (X2), corporate image (X3) with the dependent variable is customer loyalty $(Y)$. The population of this research is all consumers who transact at BSI. The sample used in this study was 50 respondents. The sampling technique used is non-probability sampling with ancillary sampling. The data collection tool used is a questionnaire. The analytical technique used is multiple linear regression analysis and hypothesis testing using SPSS for Windows software. The main results of this study are (1) corporate social responsibility has a positive and significant effect on customer loyalty, (2) service quality has a positive and significant effect on customer loyalty, has a significant effect on customer loyalty, (3) corporate image has a negative and negligible influence on customer loyalty. customer loyalty, (4) corporate social responsibility, service quality and corporate image together (at the same time) have a significant effect on customer loyalty.

Penelitian ini bertujuan untuk menganalisis pengaruh tanggung jawab sosial perusahaan, kualitas layanan dan citra perusahaan terhadap loyalitas pelanggan. Sumber data penelitian ini adalah data primer dari sampel yaitu nasabah Bank Syariah Indonesia (BSI) Cabang Surabaya. Penelitian ini merupakan penelitian kuantitatif dengan teknik penelitian kausalitas. Variabel bebas penelitian ini adalah tanggung jawab sosial perusahaan (X1), kualitas pelayanan (X2), citra perusahaan (X3) dengan variabel terikat loyalitas pelanggan $(\mathrm{Y})$. Populasi penelitian ini adalah seluruh konsumen yang bertransaksi di BSI. Sampel yang digunakan dalam penelitian ini adalah 50 responden. Teknik pengambilan sampel yang digunakan adalah non-probability sampling dengan ancillary sampling. Alat pengumpulan data yang digunakan adalah kuesioner. Teknik analisis yang digunakan adalah analisis regresi linier berganda dan pengujian hipotesis menggunakan software SPSS for Windows. Hasil utama penelitian ini adalah (1) corporate social responsibility berpengaruh positif dan signifikan terhadap loyalitas pelanggan, (2) kualitas pelayanan berpengaruh positif dan signifikan terhadap loyalitas pelanggan, berpengaruh signifikan terhadap loyalitas pelanggan, (3) citra perusahaan memiliki pengaruh negatif dan dapat diabaikan terhadap loyalitas pelanggan, (4) Tanggung jawab sosial perusahaan, kualitas layanan dan citra perusahaan secara bersama-sama (sekaligus) berpengaruh signifikan terhadap loyalitas pelanggan. 


\section{PENDAHULUAN}

Perkembangan industri keuangan syariah di Indonesia cukup berkembang pesat hingga saat ini. Lembaga keuangan syariah di Indonesia mendapatkan tempat di hati masyarakat muslim Indonesia terutama di Industri perbankan syariah. Industri perbankan syariah ternyata dapat melayani kebutuhan keuangan masyarakat melalui jasa pembiayaan dan tabungan dengan berlandaskan tanpa riba (Harun et al., 2020). Industri perbankan dan keuangan syariah ini juga memberikan sumbangan yang besar bagi kemajuan sektor riil perekonomian dan bisnis di Indonesia. Usaha untuk mempertahankan keberlangsungan bank syariah di Indonesia ternyata tidak mudah, perbankan syariah dalam kehidupannya tumbuh dan bersaing dengan bank konvensional dimana tingkat kesuksesan dari keberlangsungan dari bank syariah tergantung dari loyalitas nasabah.

Loyalitas nasabah ini ternyata tidak bisa dianggap ringan. Berbagai macam inovasi dalam usaha mempertahankan loyalitas nasabah dunia perbankan syariah telah dilakukan selama ini ternyata belum cukup menarik perhatian pasar perbankan syariah dibandingkan dengan perbankan konvensional (Suhartanto et al., 2020). Permasalahan loyalitas pelangan ini ternyata tidak hanya disebabkan hanya dari sisi bisnis saja akan tetapi ada sisi lain yang menjadi pertimbangan bagi seorang pelangan untuk dapat menjadi loyal. Beberapa peneliti (Chang \& Yeh, 2017) mengemukakan bahwa tanggung jawab social perusahaan merupakan faktor yang cukup besar dalam menciptakan loyalitas nasabah. Oleh karena itu hubungan antara tanggung jawab social atau CSR memegang peranan yang penting dalam memelihara hubungan antara perbankan syariah dengan loyalitas pelangan.

Beberapa penelitian mengenai perbankan syariah hanya mengfokuskan bahwa sebuah kesukesan dari kinerja sebuah perbankan syariah juga terletak kepada aktivitas CSR yang dilakukan oleh perusahaan (Bukhari et al., 2020); (Harun et al., 2020)., sedangkan untuk perkembangan CSR dalam hal meningkatkan loyalitas pelanggan kurang mendapatkan perhatian (Suhartanto et al., 2020), selain itu, banyak penelitian yang kurang memberi perhatian kepada faktor hubungan antara CSR, citra perusahaan, dan kualitas layanan terhadap loyalitas.
Citra perusahaan diperlukan untuk memastikan apakah CSR dapat menciptakan keunggulan Perspektif perbankan syariah di benak nasabah yang mendorong mereka untuk setia (Aramburu \& Pescador, 2019). Selain CSR dan citra perusahaan, kualitas layanan bank syariah juga mempengaruhi loyalitas nasabah, karena nasabah akan merasa nyaman dan puas dengan pelayanan yang diberikan oleh bank syariah. Kualitas pelayanan merupakan faktor penting dalam menciptakan kepuasan pelanggan, khususnya bagi perusahaan jasa. Kualitas pelayanan yang baik dapat membangun loyalitas pelanggan (Rofiki \& Nurhayati, 2020).

Mengatasi kesenjangan penelitian, penelitian ini memperkirakan loyalitas nasabah di industri perbankan syariah melalui peran aktif CSR, kualitas pelayanan, dan citra perusahaan. Secara khusus, penelitian ini memiliki meramalkan tiga jalur, yaitu; (1) hubungan langsung antara CSR dan loyalitas nasabah; (2) hubungan langsung antara dan kualitas pelayanan dan loyalitas nasabah (3) hubungan langsung antara citra perusahaan dan loyalitas nasabah (4) hubungan secara simultan antara CSR, kualitas layanan, dan citra perusahaan terhadap loyalitas nasabah. Penelitian ini dilakukan di Surabaya jawa Timur yang berada di negara Indonesia dimana penduduknya mayoritas beragama Islam

Berdasarkan penjelasan di atas bertujuan untuk menganalisis pengaruh tentang Corporate Social Responsibility (CSR) yang dikaitkan dengan Corporate Image (Citra Perusahaan), dan Service Quality (Kualitas layanan) terhadap loyalitas nasabah di Bank Syariah Indonesia Kantor Cabang Surabaya

\section{METODE PENELITIAN}

\section{Ruang Lingkup Penelitian}

Kajian ini mencakup bidang pemasaran yang membahas pengaruh Corporate Social Responsibility (CSR), Corporate Image, dan Service Quality terhadap loyalitas nasabah. Berdasarkan hal ini maka dilakukan penelitian di perusahaan jasa yaitu Bank Syariah Indonesia (BSI) untuk membuktikan bahwa Corporate Social Responsibility, Corporate Image, dan Quality Service mempengaruhi loyalitas nasabah. Pemilihan Bank Syariah Indonesia menjadi objek penelitian. Hal ini dikarenakan 
fenomena bahwa Bank Syariah Indonesia merupakan bank baru hasil pengabungan dari tiga Bank yaitu Bank Mandiri Syariah, Bank Negara Indonesia Syariah dan Bank Rakyat Indonesia Syariah dimana nasabahnya semakin membesar dan hal ini merupakan factor pendukung penelitian yang sangat memenuhi syarat sebuah penelitian.

\section{Identifikasi Variabel}

Pengertian variabel penelitian menurut (Sugiyono, 2010, p. 2) adalah segala sesuatu, dalam bentuk apapun, yang ditetapkan oleh peneliti yang sedang diteliti guna memperoleh informasi tentang dirinya dan selanjutnya menarik kesimpulan. Menurut Hatch dan Fardahany dalam(Sugiyono, 2010, p. 3), variabel secara teoritis dapat didefinisikan sebagai atribut, orang, atau objek yang menunjukkan "variasi" dari satu orang ke orang lain atau dari satu kata ke kata lain, orang ke objek lain. Penelitian ini menggunakan dua variabel yaitu:

\section{a. Variabel Bebas (Independent variable)}

Variabel bebas yang dicatat (X) adalah stimulus, prediktor, variabel sebelumnya. Dalam bahasa Indonesia sering disebut variabel bebas. Variabel yang menyebabkan berubahnya atau munculnya variabel terikat (terikat). Variabel bebas dalam penelitian ini adalah

\section{Corporate Social Responsibility (X1) \\ 2. Quality Service (X2) \\ 3. Corporate Image (X3)}

b. Variabel Terikat (dependent variable)

Variabel terkait (dependen variabel) Variabel ini sering disebut sebagai variabel output, kriteria, atau konsekuensi. Dalam bahasa Indonesia sering disebut variabel terikat. Variabel terikat adalah variabel yang dipengaruhi atau hasil, karena variabel bebas(Sugiyono, 2010, p. 4). Dalam penelitian ini variable terikatnya adalah: Loyalitas Nasabah (Y).

\section{Teknik Pengumpulan Data}

1. Penelitian kepustakaan

Penelitian ini diperoleh dengan membaca dan mempelajari literatur dan dokumendokumen yang berkaitan dengan pokok bahasan dan tujuan yang diteliti.

\section{Penelitian lapangan}

Kuesioner,adalah teknik pengumpulan informasi yang memungkinkan analisis untuk mempelajari sikap, keyakinan, perilaku, dan karakteristik beberapa orang kunci dalam organisasi yang mungkin terpengaruh oleh sistem yang ada saat ini (Siregar, 2013, p. 132)

Jenis skala yang digunakan adalah skala interval. Menurut (Riduwan, D. M., \& Akdon, 2013, p. 14) skala interval adalah skala yang mewakili jarak antara satu level data dengan level lainnya dan memiliki bobot yang sama. Kemudian, setiap indikator pertanyaan dalam kuesioner diukur dengan menggunakan skala Likert, yaitu skala yang digunakan untuk mengukur sikap, pendapat, dan persepsi seseorang atau kelompok tentang peristiwa sosial atau fenomena sosial.(Riduwan, D. M., \& Akdon, 2013, p. 16). Dalam angket yang digunakan peneliti, setiap pertanyaan terdiri dari 5 (lima) jenis jawaban, yaitu:

1. Sangat setuju/Sangat baik Skor $=5$

2. Setuju/Baik Skor $=4$

3. Cukup setuju/Cukup baik Skor $=3$

4. Tidak Setuju/Tidak baik Skor $=2$

5. Sangat tidak setuju/Sangat tidak baik Skor $=1$

\section{Populasi dan Sampel}

Menurut (Sugiyono, 2010, p. 61) populasi adalah suatu rentangan yang digeneralisasikan yang meliputi: subjek/subyek dengan kualitas dan karakteristik tertentu yang diidentifikasi oleh peneliti untuk dipelajari dan kemudian disertakan menarik kesimpulan. Dalam penelitian ini, populasinya adalah 50 nasabah Bank Syariah Indonesia (BSI). Dalam penelitian ini sampel yang akan diteliti adalah seluruh populasi yang berjumlah 50 karyawan, sehingga peneliti menggunakan sampel jenuh atau seluruh populasi yang dijadikan sampel sebagai sampel tanpa harus mengambil sejumlah sampel tertentu. Pengambilan sampel berdasarkan teknik pengambilan sampel non probabilitas (non-probability sampling), dengan teknik sampling rasional, yaitu teknik yang digunakan untuk pengambilan sampel yang bertujuan sesuai dengan persyaratan tertentu, untuk mengetahui pelanggan mana yang telah menjadi pelanggan BSI dalam tiga bulan dengan pertimbangan dalam tiga bulan. bulan sudah memiliki pengalaman, pengetahuan dan kesan 
untuk dapat mengukur loyalitas nasabah di Bank Syariah Indonesia

\section{Sumber Data}

a. Data Primer

Ini adalah data yang biasanya diperoleh dari subjek penelitian melalui observasi atau eksperimen. Alat pengumpulan data yang utama biasanya adalah observasi langsung, subjek diberi selembar kertas dengan pertanyaan untuk diisi, pertanyaan untuk responden(Sujarweni \& Endrayanto, 2012, p. 21).

b. Data Sekunder

Data sekunder adalah data yang tidak berasal langsung dari sumber primer dan telah disusun menjadi bahan tertulis. Data ini biasanya diperoleh dari buku cetak (Sujarweni, W. W., \& Endrayanto, 2012, p. 21)

\section{HASIL DAN PEMBAHASAN}

\section{Hasil}

\section{Gambaran Umum Objek Penelitian}

Indonesia yang memiliki penduduk muslim terbesar di dunia berpotensi menjadi yang terdepan dalam keuangan syariah. Peningkatan kesadaran publik akan isu halal dan dukungan kuat dari pemangku kepentingan merupakan faktor penting dalam pengembangan ekosistem industri halal di Indonesia. Termasuk bank syariah. Bank Syariah memainkan peran penting sebagai fasilitator dalam semua kegiatan ekonomi ekosistem industri halal. Keberadaan sektor perbankan syariah di Indonesia telah mengalami pertumbuhan dan perkembangan yang signifikan selama tiga dekade terakhir. Inovasi produk, peningkatan layanan dan pengembangan jaringan menunjukkan tren positif dari tahun ke tahun. Bahkan, semangat akselerasi juga tercermin dari banyaknya bank syariah yang melakukan percepatan usaha. Tak terkecuali bank syariah milik bank umum yaitu Bank Mandiri Syariah, BNI Syariah dan BRI Syariah.

Pada tanggal 1 Februari 2021 yang bertepatan dengan 19 Jumadil Akhir $12 \mathrm{H}$, menandai sejarah penggabungan Bank Syariah Mandiri, BNI Syariah dan BRI Syariah menjadi satu kesatuan, yaitu Bank Syariah Indonesia (BSI). Penggabungan ini akan menyatukan kekuatan ketiga bank syariah untuk memberikan layanan yang lebih lengkap, jangkauan yang lebih luas, dan permodalan yang lebih baik. Didukung sinergi perusahaan induk (Mandiri, BNI, BRI) dan keterlibatan pemerintah melalui Kementerian BUMN, Bank Syariah Indonesia terdorong untuk bersaing secara global. Penggabungan ketiga bank syariah tersebut merupakan upaya untuk mewujudkan bank syariah yang menjadi kebanggaan masyarakat, menjadi sumber energi baru bagi pembangunan ekonomi nasional dan memberikan kontribusi bagi kesejahteraan masyarakat tembaga pada umumnya. Keberadaan Bank Syariah Indonesia juga mencerminkan wajah perbankan syariah di Indonesia modern yang populer dan bermanfaat bagi seluruh dunia. (Indonesia, 2021).

\section{Gambaran Penyebaran Kuesioner}

Penelitian ini menggunakan kuesioner yang disebarkan langsung kepada responden nasabah BSI Kantor Cabang Surabaya. Responden dalam penelitian ini adalah BSI Kantor Cabang Surabaya sejumlah 50 orang kuesioner yang dikirimkan kepada seluruh responden dapat dibuat ikhtisarnya sebagai berikut:

\section{Gambaran Umum Kuisioner}

Berdasarkan Tabel 2, dapat dilihat bahwa deskripsi data akan disajikan berdasarkan hasil penelitian ini untuk memberikan gambaran umum tentang kuesioner yang akan dibagikan kepada responden. Jumlah pertanyaan dalam angket yang dikirimkan sebanyak 50 orang, dengan ringkasan sebagai berikut:

Tabel 2 Gambaran Umum Kuesioner

\begin{tabular}{|c|c|c|c|}
\hline Var & Variabel & $\begin{array}{l}\text { Skala } \\
\text { Likert } \\
\end{array}$ & Jumlah \\
\hline $\mathrm{X} 1$ & $\begin{array}{l}\text { Variabel Corporate } \\
\text { Social } \\
\text { Responsibilty } \\
\text { (CSR) }\end{array}$ & $1-5$ & 4 Pertanyaan \\
\hline $\mathrm{X} 2$ & $\begin{array}{l}\text { Variabel Quality } \\
\text { Service }\end{array}$ & $1-5$ & 5 Pertanyaan \\
\hline X3 & $\begin{array}{l}\text { Variabel Corporate } \\
\text { Image }\end{array}$ & $1-5$ & 4 Pertanyaan \\
\hline $\mathrm{Y}$ & Loyalitas Nasabah & $1-5$ & 3 Pertanyaan \\
\hline & Jumlah Pertanyaan & & 16 Pertanyaan \\
\hline
\end{tabular}

Sumber data: Hasil Olahan Kuesioner, 2021

\section{Karakteristik Responden}

Responden dalam penelitian ini merupakan nasabah BSI Kantor Cabang Surabaya sebanyak 50 orang. Keseluruhan 
responden tersebut dapat diketahui karakteristiknya berdasarkan jenis kelamin, usia, pendidikan, pekerjaan, dan pengeluaran per bulan.

\section{Uji Serentak (Uji F)}

Uji $F$ dilakukan untuk mengetahui apakah variabel Corporate Social Responsibility $\left(\mathrm{X}_{1}\right)$ Quality Service $\left(\mathrm{X}_{2}\right)$, dan Corporate Image (X3) secara simultan (bersama-sama) berpengaruh terhadap loyalitas nasabah BSI Kantor Cabang Surabaya. Hasil uji simultan dapat disajikan pada Tabel 3 sebagai berikut:

Tabel 3. Hasil Uji F

ANOVA $^{\mathrm{a}}$

\begin{tabular}{lccccc}
\hline \multicolumn{1}{c}{ Model } & $\begin{array}{c}\text { Sum of } \\
\text { Squares }\end{array}$ & df & $\begin{array}{c}\text { Mean } \\
\text { Square }\end{array}$ & F & Sig. \\
\hline Regression & 394.867 & 3 & 131.622 & 23.578 & $.000^{\mathrm{b}}$ \\
Residual & 535.883 & 96 & 5.583 & & \\
Total & 930.750 & 99 & & & \\
\hline
\end{tabular}

a. Dependent Variable: Tot_Y

b. Predictors: (Constant), Tot_X3, Tot_X2, Tot_X1

Sumber : Hasil Output SPSS 24

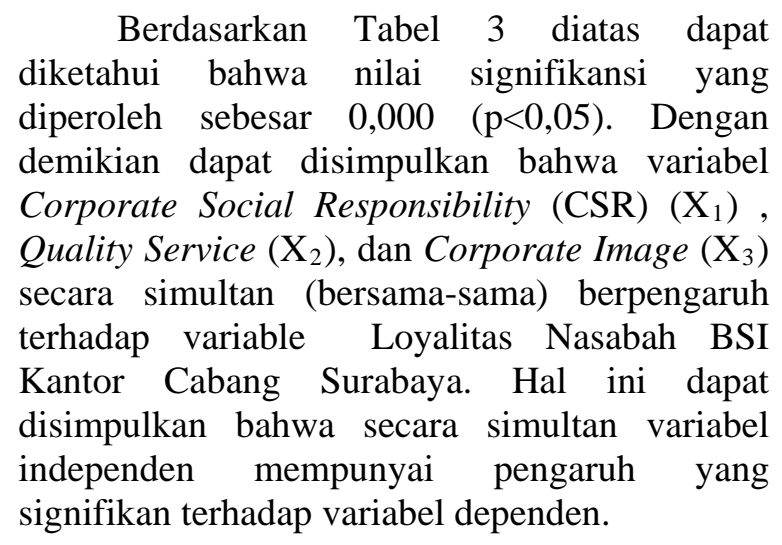

\section{Uji Parsial (Uji t)}

Uji t digunakan untuk menguji koefisien regresi secara parsial dari variabel independennya, apakah masing-masing variabel Corporate Social Responsibility $\left(\mathrm{X}_{1}\right)$, Quality Service $\left(\mathrm{X}_{2}\right)$, dan Corporate Image $\left(\mathrm{X}_{3}\right)$ berpengaruh terhadap variabel Loyalitas Nasabah BSI Kantor Cabang Surabaya. Kriteria Loyalitas Nasabah yaitu dengan melihat nilai signifikansi masing-masing variabel yang akan dibandingkan nilai derajat kesalahan sebesar $5 \%$.

Tabel 4 Hasil Uji t

Coefficients $^{\mathrm{a}}$

Improvement: Jurnal Manajemen dan Bisnis

Vol. 1 No. 2 September 2021

\begin{tabular}{cccccc}
\hline \multirow{2}{*}{ Model } & \multicolumn{2}{c}{ Unstand. Coeff } & \multirow{2}{*}{$\mathrm{t}$} & Sig. \\
\cline { 3 - 4 } & \multicolumn{1}{c}{ B } & \multicolumn{2}{c}{ Std. Error } & & \\
\hline \multirow{4}{*}{} & (Constant) & 3.055 & 2.749 & 1.111 & 026 \\
1 & Tot_X1 & 364 & 088 & 4.133 & 000 \\
& Tot_X2 & 325 & 082 & 3.971 & 000 \\
& Tot_X3 & -115 & 088 & -1.311 & 019 \\
\hline
\end{tabular}

a. Dependent Variable: Tot_Y

Sumber : Hasil Output SPSS 24 (Lampiran 6)

Berdasarkan Tabel 4 diatas, dapat dituliskan model regresi linier berganda mengenai pengaruh variabel Corporate Social Responsibility $\left(\mathrm{X}_{1}\right)$, Quality Service $\left(\mathrm{X}_{2}\right)$, dan Corporate Image $\left(\mathrm{X}_{3}\right)$ terhadap variabel Loyalitas Nasabah BSI Kantor Cabang Surabaya sebagai berikut:

$\mathrm{Y}=3,005+0,364 \mathrm{X} 1+0,325 \mathrm{X} 2+(-0,115)$ $\mathrm{X} 3$ berikut:

Interpretasi hasil uji parsial adalah sebagai

1. Konstanta $(\alpha)$ sebesar 3.055 memberi arti apabila variabel bebas Corporate Social Responsibility $\left(\mathrm{X}_{1}\right)$, Quality Service $\left(\mathrm{X}_{2}\right)$ dan Corporate Image $\left(\mathrm{X}_{3}\right)$ adalah bernilai Konstan, maka besarnya variabel terikat yaitu Loyalitas Nasabah (Y) adalah bernilai sebesar 3.055 satuan.

2. Variabel Corporate Social Responsibility $\left(\mathrm{X}_{1}\right)$ memiliki koefisien sebesar 364 yang menunjukkan pengaruh positif (searah) terhadap Loyalitas Nasabah (Y). Apabila Corporate Social Responsibility ( $\left.\mathrm{X}_{1}\right)$ bertambah satu satuan, maka Loyalitas Nasabah (Y) akan bertambah sebesar 364 satuan.

3. Variabel Quality Service $\left(\mathrm{X}_{2}\right)$ memiliki koefisien sebesar 325 yang menunjukkan pengaruh positif (searah) terhadap Loyalitas Nasbah (Y). Apabila Corporate Social Responsibility $\left(\mathrm{X}_{2}\right)$ bertambah satu satuan, maka Loyalitas Nasabah (Y) akan bertambah sebesar 325 satuan

4. Variabel Corporate Image $\left(\mathrm{X}_{3}\right)$ memiliki koefisien sebesar -115 yang menunjukkan pengaruh negatif (berlawanan) terhadap Loyalitas Nasabah (Y). Apabila Corporate Image $\left(\mathrm{X}_{3}\right)$ berkurang satu satuan, maka Loyalitas Nasabah (Y) akan berkurang sebesar -115 satuan.

\section{Koefisien Determinasi}


Uji $\mathrm{R}^{2}$ digunakan untuk mengukur seberapa jauh kemampuan model dalam menjelaskan variabel dependen. Dalam penelitian ini koefisien determinasi menggunakan nilai adjusted $\mathrm{R}^{2}$.

Tabel 5 Koefisien Determinasi

\begin{tabular}{ccccc} 
& \multicolumn{4}{c}{ Model Summary $^{\mathrm{b}}$} \\
\hline Model & $\mathrm{R}$ & R Square & $\begin{array}{c}\text { Adjusted R } \\
\text { Square }\end{array}$ & $\begin{array}{c}\text { Std. Error of } \\
\text { the Estimate }\end{array}$ \\
\hline 1 & $651^{\mathrm{a}}$ & 424 & 406 & 2.362 \\
\hline
\end{tabular}

a. Predictors: (Constant), Tot_X3,Tot_X2, Tot_X1

b. Dependent Variable: Tot_Y

Sumber : Hasil Output SPSS 24

Dari hasil koefisien determinasi, diperoleh nilai adjusted $\mathrm{R}^{2}$ sebesar 651 atau $65,1 \%$. Hal ini menunjukkan bahwa Loyalitas Nasabah di PT. Sumber Nusantara Aditya Pratama Surabaya dapat dijelaskan sebesar 34,9\% oleh variabel independen yaitu Corporate Social Responsibility $\left(\mathrm{X}_{1}\right)$, Quality Service $\left(\mathrm{X}_{2}\right)$ dan Corporate Image $\left(\mathrm{X}_{3}\right)$. Sedangkan $59.4 \%$ variabel Loyalitas Nasabah di BSI Kantor Cabang Surabaya dijelaskan oleh variabelvariabel lain diluar variabel independen penelitian ini.

\section{Hasil Hipotesis Penelitian}

Dari hasil penelitian yang dilakukan oleh peneliti diperoleh hasil temuan penelitian yang dapat dijelaskan pada Tabel 6 sebagai berikut:

Tabel 6 Temuan Penelitian

\begin{tabular}{cl}
\hline Hipotesis & \multicolumn{1}{c}{ Temuan Penelitian } \\
\hline & Terdapat pengaruh yang signifikan \\
antara Corporate Social Responsibility & terhadap Loyalitas Nasabah dengan \\
H1 & nilai signifikansi yang diperoleh sebesar \\
& 0,000 (p<0,05). \\
& Terdapat pengaruh yang signifikan \\
& antara Quality Service terhadap \\
& Loyalitas Nasabah dengan nilai \\
H2 & signifikansi yang diperoleh sebesar \\
& 0,000 (p<0,05). \\
& Terdapat pengaruh yang signifikan \\
& antara Corporate Image terhadap \\
& Loyalitas Nasabah dengan nilai tidak \\
& signifikan yang diperoleh sebesar 0,193 \\
& (p>0,05). \\
& Terdapat pengaruh yang tidak signifikan \\
& antara Corporate Social Responsibility, \\
& Quality Service dan Corporate Image \\
& terhadap Loyalitas Nasabah dengan \\
& nilai signifikansi yang diperoleh sebesar \\
\hline
\end{tabular}

$0,260(p>0,05)$.

Sumber : Hasil Peneliti 2021

\section{Pembahasan \\ Pengaruh Corporate Social Responsibility Terhadap Loyalitas Nasabah}

Berdasarkan hasil pengujian pada penelitian ini menyatakan bahwa Corporate Social Responsibility berpengaruh signifikan terhadap Loyalitas Nasabah dan memiliki nilai yang positif. Hasil tersebut terlihat pada nilai signifikan sebesar 0,000 yang lebih kecil dari tingkat signifikan 0,05 atau nilai t hitung yang lebih besar dari pada $t$ Tabel dan memiliki nilai B positif yaitu sebesar 0,364. Hal ini menjelaskan bahwa hasil penelitian ini menunjukan kondisi yang signifikan yang berarti semakin tinggi Corporate Social Responsibility yang dijalankan maka tingkat Loyalitas Nasabah semakin tinggi atau naik sebesar 0,364 atau sebesar 36,4\%. Jika dilihat dari hasil kuesioner yang ada para responden lebih dominan setuju bahkan memilih sangat setuju dengan pernyataan yang ada, ini membuktikan bahwa responden yang termasuk dalam penelitian ini sudah sangat mendukung program CSR yang dilakukan oleh BSI Kantor Cabang Surabaya walaupun ada juga beberapa responden yang memilih untuk netral dalam pengimplementasian CSR yang dilakukan BSI namun persentase dari pendapat mereka sedikit.

CSR yang dilakukan BSI merupakan sebuah bentuk komitmen perusahaan kepada lingkungan dengan tujuan memberikan nilai tambah kepada semua pemilik kepentingan termasuk internal perusahaan dalam rangka mendukung pertumbuhan perusahaan. BSI berhasil melakukan pengimplementasian CSR dengan baik secara internal maupun eksternal. CSR ini mengharuskan perusahaan harus selalu melakukan implementasi dalam rangka mewujudkan hubungan harmonis antara perusahaan dan masyarakat, membangun citra positif dalam upaya pelestarian lingkungan hidup, peningkatan kulalitas pendidikan, kesehatan, kesejahteraan, kehidupan, dan perbaikan sarana lainnya.

\section{Pengaruh Quality Service Terhadap Loyalitas Nasabah}

Berdasarkan hasil pengujian pada penelitian ini menyatakan bahwa Quality Service 
berpengaruh positif dan signifikan terhadap Loyalitas Nasabah. Hasil tersebut terlihat pada nilai signifikan yaitu 0,000 yang mana nilai ini lebih kecil dari tingkat signifikan 0,05 atau t hitung lebih besar dari pada $t$ Tabel dan memiliki nilai B positif yaitu sebesar 0,325. Hasil penelitian ini menunjukan kondisi yang signifikan dan positif yang berarti semakin baik persepsi pelanggan terhadap Quality Service yang dijalankan maka semakin tinggi tingkat Loyalitas Nasabah atau sebaliknya semakin buruk persepsi pelanggan terhadap Quality Service maka semakin rendah Loyalitas Nasabah. Jika dilihat dari hasil kuesioner yang ada para responden lebih dominan setuju bahkan memilih sangat setuju dengan pernyataan yang ada, ini membuktikan bahwa responden yang termasuk dalam penelitian ini sudah merasa puas dengan target yang telah ditentukan walaupun ada juga beberapa responden yang memilih untuk kurang setuju bahkan sangat tidak setuju dalam kriteria Quality Service yang ditentukan.

Quality Service memang menjadi salah satu hal yang penting pada saat perusahaan ingin menetapkan penentuan target pasar yang akan dimasukinya karena jika terjadi kesalahaan maka bisa berujung pada ketidaktertarikan akan produk tersebut namun sebaliknya jika penetapan target pasar yang ditetapkan sangat sesuai maka akan terjadi efek loyalitas dalam benak konsumen dan hal itulah yang terjadi pada BSI Cabang Kota Surabaya yang menetapkan bahwa Quality Service untuk semua kalangan, para pelanggan merasa cocok dan sesuai dengan keinginan mereka sehingga menciptakan efek loyal bagi pelanggan dengan Quality Service yang telah ditetapkan perusahaan juga mengimbangi dengan fasilitas yang menunjang untuk mendapatkan nilai tambah dari para pelanggan. Kemudian untuk para pesaing yang ada harus juga menjadi sorotan dari BSI Cabang Kota Surabaya karena meskipun memiliki target yang sama, para pesaing mungkin saja menawarkan fasilitas atau kualitas layanan yang tidak ditawarkan oleh BSI Cabang Kota Surabaya dan bukan tidak mungkin pelanggan BSI beralih kepada bank pesaing. Hal ini sesuai dengan teori (Kotler, P., \& Keller, 2016) dari loyalitas yakni kembali membeli ulang_produk (repeat purchase), resistensi pada efek negatif dari perusahaan (retention), dan total referensi keberadaan perusahaan (referalls) Keberhasilan CSR harus diikuti dengan tahap Quality Service atau kualitas layanan yang ingin dituju dengan benar. Target pasar dari pihak BSI adalah semua kalangan.

\section{Pengaruh Corporate Image Terhadap Loyalitas Nasabah}

Berdasarkan hasil pengujian pada penelitian ini menyatakan bahwa Corporate Image berpengaruh negatif dan tidak signifikan terhadap Loyalitas Nasabah. Hasil tersebut terlihat pada nilai signifikansi yaitu 0,193 yang mana nilai ini lebih besar dari tingkat signifikan 0,05 atau t hitung lebih kecil dari pada t Tabel dan memiliki nilai B negatif yaitu sebesar 0.115. Hasil ini menjelaskan bahwa hasil penelitian ini menunjukan kondisi yang tidak signifikan dan berpengaruh negatif dalam Loyalitas Nasabah.

BSI Cabang Kota Surabaya adalah bank syariah yang diharapkan mampu bersaing dengan bank konvensional yang sudah terkenal didalam negeri. Sebagian nasabah merasa bahwa citra perusahaan belum mewakili untuk seseorang loyal terhadap suatu bank. Alasan inilah yang membuat BSI Cabang Kota Surabaya mendapatkan respon yang kurang baik dari para nasabah. BSI Cabang Kota Surabaya harus membuat kesan yang mendalam terhadap nasabah dengan memberikan layanan ataupun kepercayaan bahwa di kondisi apapun BSI Cabang Kota Surabaya bisa melayani nasabahnya tanpa memandang jenis nasabah dimana dalam pandangan masyarakat umum susah untuk dijangkau bagi masyarakat bawah Misalnya dengan memberi banyak kemudahan masyarakat bawah memiliki akses Sehingga produk BSI Cabang Kota Surabaya dapat mendapatkan image yang baik di benak para konsumen.

\section{Pengaruh Corporate Social Responsibility, Quality Service, dan Corporate Image Terhadap Loyalitas Nasabah}

Hasil pengujian yang dilakukan, Corporate Social Responsibility dan Quality Service berpengaruh secara simultan terhadap Loyalitas Nasabah. Hasil tersebut terlihat pada nilai signifikan sebesar 0,000 yang lebih kecil dari batas taraf signifikan yaitu 0,05 atau dilihat dari nilai $\mathrm{F}$ hitung dan $\mathrm{F}$ Tabel yang dimana $\mathrm{F}$ hitung harus lebih besar dari F tabel. Hasil tersebut menunjukan bahwa Corporate Social Responsibility dan Quality Service secara simultan berpengaruh terhadap Loyalitas Nasabah. Dan variabel Corporate Image tidak 
berpengaruh secara simultan terhadap Loyalitas Nasabah, karena dari hasil yang terlihat nilai signifikan Corporate Image sebesar 0,193 > dari batas signifikan yaitu 0,05 . Hasil penelitian ini memberikan temuan baru bahwa citra perusahaan tidak menjadikan sebuah alasan atau dasar bagi seorang nasabah untuk menjadi nasabah yang loyal di perusahaan tersebut.

\section{Simpulan}

Simpulan yang diperoleh berdasarkan penelitian ini adalah sebagai berikut:

(1) Variabel segmenting secara parsial berpengaruh positif dan signifikan terhadap Loyalitas Nasabah pada BSI Cabang Kota Surabaya Sidoarjo (2) Variabel Quality Service secara parsial berpengaruh positif dan signifikan terhadap Loyalitas Nasabah pada BSI Cabang Kota Surabaya Sidoarjo (3) Variabel Corporate Image secara parsial berpengaruh negatif dan tidak signifikan terhadap Loyalitas Nasabah pada BSI Cabang Kota Surabaya Sidoarjo. (4) Variabel segmenting, Quality Service dan Corporate Image secara bersama-sama (simultan) berpengaruh signifikan terhadap Loyalitas Nasabah pada BSI Cabang Kota Surabaya Sidoarjo (5) Variabel segmenting merupakan variabel dominan yang mempengaruhi Loyalitas Nasabah di BSI Cabang Kota Surabaya Sidoarjo.

\section{DAFTAR PUSTAKA}

Aramburu, I. A., \& Pescador, I. G. (2019). The Effects of Corporate Social Responsibility on Customer Loyalty: The Mediating Effect of Reputation in Cooperative Banks Versus Commercial Banks in the Basque Country. Journal of Business Ethics, 154(3), 701-719. https://doi.org/10.1007/s10551-017-3438-1

Bukhari, S. A. A., Hashim, F., \& Amran, A. Bin. (2020). Determinants and outcome of Islamic corporate social responsibility (ICSR) adoption in Islamic banking industry of Pakistan. Journal of Islamic Marketing, 12(4), 730-762. https://doi.org/10.1108/JIMA-11-20190226

Chang, Y. H., \& Yeh, C. H. (2017). Corporate social responsibility and customer loyalty in intercity bus services. Transport Policy, 59(October 2016), 38-45. https://doi.org/10.1016/j.tranpol.2017.07.0
01

Harun, M. S., Hussainey, K., Mohd Kharuddin, K. A., \& Farooque, O. Al. (2020). CSR Disclosure, Corporate Governance and Firm Value: a study on GCC Islamic Banks. International Journal of Accounting and Information Management, 28(4), 607-638. https://doi.org/10.1108/IJAIM-08-20190103

Indonesia, B. S. (2021). Sejarah Perseroan. https://ir.bankbsi.co.id/corporate_history.ht $\mathrm{ml}$

Kotler, P., \& Keller, K. L. (2016). Marketing Manajemen (14ed). New Jersey: Pearson Pretice Hall, Inc.

Riduwan, D. M., \& Akdon, P. D. (2013). Rumus dan Data dalam Analisis Statistika. Alfabeta.

Rofiki, A., \& Nurhayati, N. (2020). PENGARUH CORPORATE SOCIAL RESPONSIBILITY DAN KUALITAS PELAYANAN TERHADAP LOYALITAS NASABAH MELALUI SIKAP NASABAH (Studi Pada Bank Muamalat KC. Malang). J-MACC: Journal of Management and Accounting, 3(1), 83-96. https://doi.org/10.52166/jmacc.v3i1.1860

Siregar, S. I. (2013). Statistik Parametrik untuk Penelitian Kuantitatif. Bumi Aksara.

Sugiyono. (2010). Metode Penelitian Pendidikan Pendekatan Kuantitatif, kualitatif dan $R \& D$. Alfabeta.

Suhartanto, D., Gan, C., Sarah, I. S., \& Setiawan, S. (2020). Loyalty towards Islamic banking: service quality, emotional or religious driven? Journal of Islamic Marketing, 11(1), 66-80. https://doi.org/10.1108/JIMA-01-20180007

Sujarweni, W. W., \& Endrayanto, P. (2012). Statistika Untuk Penelitian. Graha Ilmu. 